\title{
PENGARUH MOTIVASI KERJA DAN DISIPLIN KERJA TERHADAP PRODUKTIVITAS KERJA PADA KARYAWAN PT. KABELINDO MURNI, TbK.
}

\author{
Roni Faslah \\ Dosen Fakultas Ekonomi Universitas Negeri Jakarta \\ Meghar Tremtari Savitri \\ Alumni Fakultas Ekonomi Universitas Negeri Jakarta
}

\begin{abstract}
ABSTRAK
Penelitian ini bertujuan untuk mengetahui apakah terdapat pengaruh antara motivasi kerja dan disiplin kerja terhadap produktivitas kerja pada karyawan PT. Kabelindo Murni, Tbk. Metode penelitian yang digunakan adalah metode survey dengan pendekatan korelasional. Populasi terjangkau penelitian ini adalah seluruh karyawan produksi PT. Kabelindo Murni, Tbk sebanyak 139 orang. Sampel yang digunakan sebanyak 100 orang karyawan. Persamaan regresi yang didapat adalah $\hat{Y}=-145.950+0.633 \mathrm{X} 1+1.987 \mathrm{X} 2$. Uji hipotesis yaitu uji $F$ dalam tabel ANOVA menghasilkan $F_{\text {hitung }}(29.801)>F_{\text {tabel }}(3,11)$, hal ini berarti $\mathrm{X}_{1}$ (Motivasi Kerja) dan $\mathrm{X}_{2}$ (Disiplin Kerja) secara bersama - sama memiliki pengaruh dengan $Y$ (Produktivitas Kerja). Uji t menghasilkan thitung dari $X_{1}$ (Motivasi Kerja) sebesar 4,903 dan thitung dari $X_{2}$ (Disiplin Kerja) sebesar 4.166 dan $t_{\text {tabel }}$ sebesar 1,66 karena $t_{\text {hitung }}$ lebih besar dari $t_{\text {tabel }}$. Kemudian uji koefisien determinasi diperoleh hasil 38,1\% yang berarti bahwa variabel $Y$ (Produktivitas Kerja) ditentukan oleh $X_{1}$ (Motivasi Kerja) dan $X_{2}$ (Disiplin Kerja) secara simultan yaitu $38,1 \%$. Kesimpulan penelitian ini adalah terdapat pengaruh yang positif dan signifikan antara motivasi kerja dengan produktivitas kerja dan disiplin kerja dengan produktivitas kerja pada karyawan.
\end{abstract}

Kata kunci: motivasi kerja, disiplin, produktivitas

\section{PENDAHULUAN}

Untuk bersaing secara kompetitif dalam era globalisasi ini, maka perusahaan membutuhkan karyawan yang cakap dan berkualitas yang dapat memberi dukungan bagi perusahaan untuk mencapai tujuan perusahaan, serta memiliki sikap mental yang baik, mempunyai semangat kerja yang tinggi sehingga dapat memanfaatkan dan mengendalikan 
sumber daya lainnya. Semangat kerja yang tinggi tercermin pula dalam motivasi kerja yang berarti mengacu pada dorongan dan usaha untuk memuaskan kebutuhan suatu tujuan dalam perusahaan. Mengingat kedudukan karyawan dalam suatu perusahaan sangat penting, maka karyawan diharapkan dapat memberikan kontribusi sehingga tujuan perusahaan akan tercapai. Dalam kegiatan di perusahaan, seringkali pihak manajemen menemukan kesulitan dalam mengatur para karyawan. Permasalahan ini mencakup bagaimana mengoptimalkan motivasi kerja dan disiplin kerja yang tinggi, yang tentunya dapat mempengaruhi produktivitas kerja karyawan.

Bagi karyawan, tingkat produktivitas kerja yang tinggi dapat memberikan keuntungan tersendiri, seperti peningkatan gaji, memperluas kesempatan untuk dipromosikan, serta membuat ia semakin ahli dan berpengalaman dalam bidang pekerjaannya. Oleh sebab itu, pemimpin harus benarbenar memberikan perhatian terhadap faktor-faktor yang mempengaruhi produktivitasi kerja. Banyak hal yang mempengaruhi produktivitas kerja, diantaranya motivasi kerja, stres kerja, insentif, lingkungan kerja, pelatihan dan disiplin kerja.

Hal yang penting bagi pemimpin perusahaan adalah memotivasi para karyawannya agar mereka dapat menjadi karyawan yang produktif dan efektif dalam pekerjaan. Upaya memotivasi karyawan dapat menyebabkan karyawan mampu meningkatkan produktivitas kerjanya sehingga tanggung jawabnya untuk meningkatkan produksi semakin besar.

Motivasi kerja merupakan pemberian daya gerak yang menciptakan keinginan kerja seseorang agar mereka mau bekerja sama, bekerja efektif dan terintegrasi dengan segala daya dan upayanya untuk mencapai kepuasan kerja. Pemberian motivasi sangat penting dalam setiap perusahaan, dengan adanya motivasi merupakan hal yang menyebabkan, menyalurkan, dan mendukung perilaku manusia agar bekerja giat untuk mencapai hasil maksimal. Karyawan yang memiliki motivasi kerja yang tinggi akan dapat mendorong dirinya sendiri untuk bekerja lebih giat dan selalu berinspirasi serta bersemangat dalam melakukan pekerjaannya. Motivasi juga dapat menggerakkan dan menuntun karyawan dalam mencapai sasaran, membantu 
dalam mengambil inisiatif dan bertindak secara efektif sehingga dapat mencapai tujuan yang telah ditetapkan.

Seorang karyawan yang baik pasti akan terus termotivasi dan memberikan kontribusi untuk keberhasilan perusahaan. Semakin tinggi motivasi yang diberikan seorang karyawan demi untuk pencapaian peningkatan perusahaannya, maka akan semakin meningkat pula produktivitas kerja karyawan dalam perusahaan.

Untuk menciptakan produktivitas kerja karyawan tidak mudah, banyak faktor yang mempengaruhinya diantaranya adalah motivasi kerja dan disiplin kerja karyawan pada perusahaan. Faktor lain yang tidak kalah pentingnya dalam meningkatkan produktivitas kerja karyawan adalah insentif. Insentif merupakan suatu alat yang digunakan untuk dapat memenuhi apa yang diinginkan karyawan.

Faktor disiplin kerja merupakan salah satu faktor yang penting dalam terciptanya produktivitas kerja yang tinggi. Setiap perusahaan memiliki manajemen yang dilengkapi dengan peraturan dan ketentuan kerja yang jelas untuk dilaksanakan oleh seluruh karyawan dari tingkat bawah sampai tingkat atas. Sebagai karyawan, setiap tindakan dan perbuatan yang dilakukan harus sesuai dengan peraturan yang telah ditetapkan oleh perusahaan. Namun pada kenyataannya, saat ini masih terdapat karyawan yang melanggar aturan jam tata tertib kerja yang sudah di tentukan oleh perusahaan, hal ini di karenakan kurangnya rasa tanggung jawab seorang karyawan terhadap tugas yang dibebankan kepadanya sehingga mempengaruhi produktivitas kerja karyawan.

\section{KAJIAN PUSTAKA \\ Produktivitas Kerja

$$
\text { Triton P.B }
$$

mendefinisikan bahwa Produktivitas kerja sebagai perbandingan hasilhasil yang dicapai dengan keseluruhan sumber daya yang di pergunakan atau perbandingan jumlah produksi (output) dengan sumber daya yang digunakan (input). Dengan begitu produktivitas merupakan ukuran hubungan antara input (tenaga kerja, modal, sumber daya alam, energi, dan lain-lain) dengan kualitas dan kuantitas output (barang dan jasa). Hal serupa di jelaskan Greeberg yang dikutip oleh Robert L. Mathis (2001:12) mendefinisikan "produktivitas kerja sebagai perbandingan antara totalitas 
pengeluaran pada waktu tertentu dibagi totalitas masukan selama periode tersebut".

Ukuran produktivitas kerja yang paling terkenal berkaitan dengan tenaga kerja yang dapat dihitung dengan membagi pengeluaran oleh jumlah yang digunakan atau jam-jam kerja karyawan dalam suatu perusahaan. Sedangkan definisi produktivitas kerja menurut Zainal Mustafa Eq (2007:179-192), yaitu "perbandingan antara hasil yang dapat dicapai dengan pemakaian mesin secara

tepat dan peran tenaga kerja yang bersangkutan per satuan waktu. Secara matematis, jika hasil kerja atau output $=0$ dan peran tenaga kerja atau input $=1$ maka produktivitas kerja $=(0 / 1) * 100 \% " .3$ Seorang tenaga kerja dinilai produktif jika yang bersangkutan mampu menghasilkan output lebih banyak dalam satuan waktu tertentu. Jika produktivitas kerja hanya dikaitkan dengan waktu saja, maka jelas kiranya bahwa produktivitas kerja sangat tergantung pada segi keterampilan dan keahlian tenaga kerja secara fisik.

Menurut Tjutju Yuniarsih (2009 : 160-161) menyatakan bawah produktivitas kerja ditentukan oleh dukungan semua sumberdaya organisasi,yang dapat diukur dari segi efektifitas dan efisiensi. Dalam hal ini, efektivitas dan efisiensi yang difokuskan pada aspek-aspek: 1) hasil akhir (produk nyata) yang dicapai, baik dilihat dari kualitas maupun kuantitasnya; 2) penggunaan sumberdaya secara optimal; serta 3) kerjasama dengan permintaan pasar atau pengguna.

Pendapat ini sejalan dengan pandangan Blecher (Wibowo, 2008:241) "produktivitas kerja adalah hubungan antara keluaran atau hasil organisasi dengan masukan yang diperlukan." Produktivitas dapat

dikuantifikasi dengan membagi keluaran dengan masukan. Menaikkan produktivitas dapat dilakukan dengan memperbaiki rasio produktivitas, dengan menghasilkan lebih banyak keluaran atau output yang lebih baik dengan tingkat masukan sumber daya tertentu. Dalam hal ini, produktivitas kerja dapat dinilai penggunaan sumber daya, waktu yang ditempuh dalam mengerjakan pekerjaanya, teknik yang ia gunakan dan tentunya dengan hasil yang diperoleh dari proses kegiatan tersebut.

Sasaran utama manajemen sumber daya manusia adalah menciptakan sistem memberdayakan personil yang 
dapat menampilkan kinerja produktif. Produktivitas kerja menunjukan tingkat kemampuan pegawai dalam mencapai hasil (output), terutama dilihat dari sisi kuantitasnya. Oleh karena itu tingkat produktivitas kerja setiap pegawai bisa berbeda, bisa tinggi dan bisa juga rendah tergantung pada tingkat kegigihan dalam menjalani tuganya.

Menaikan produktivitas pekerja berarti mengupayakan agar pekerja menghasilkan lebih banyak output selama periode waktu yang sama. Perusahaan dapat menaikan produktivitas pekerja dengan meminta para pekerja yang ada bekerja lebih keras atau dengan memperbaiki proses-proses kerja.

Dengan

demikian, produktivitas kerja dapat diartikan sebagai hasil nyata (produk) yang dihasilkan oleh individu ataupun kelompok, selama satuan waktu tertentu dalam suatu proses kerja. Dalam hal ini, semakin tinggi produk yang dihasilkan dalam waktu yang semakin singkat dapat dikatakan bahwa tingkat produktivitasnya mempunyai nilai yangt tinggi.

Whitemore (Sedarmayanti, 2011:198) "productivity is measure of the use of the resourcesof an organizationand is usually expressedas a ratio of the output obtained by the use resources to the amount of resources employee.
Dalam hal ini Whitemore memandang produktivitas kerja sebagai ukuran atas penggunaan sumber daya organisasi yang dinyatakan sebagai rasio antara output yang dicapai dengan sumber daya yang digunakan.

Dari beberapa pendapat di atas dapat disimpulkan produktivitas kerja adalah perbandingan antara hasil yang diperoleh (output) dengan sumber daya yang digunakan sebagai masukan (input) selama satuan waktu tertentu dalam suatu proses kerja.

\section{Disiplin Kerja}

Disiplin yang baik mencerminkan besarnya rasa tanggung jawab seseorang terhadap tugas-tugas yang diberikan kepadanya. Hal ini mendorong gairah kerja, semangat kerja, dan terwujudnya tujuan perusahaan. Menurut I.G Wursanto (2001:108) memberikan definisi mengenai "disiplin kerja, yaitu keadaan yang menyebabkan atau memberikan dorongan kepada karyawan untuk bekerja dan melakukan segala kegiatan sesuai dengan norma-norma dan aturanaturan yang telah ditetapkan.

Disiplin kerja menurut Pandji Anoraga (2004:178) diartikan sebagai "sikap karyawan yang senantiasa berkehendak untuk 
mengikuti atau mematuhi segala peraturan dalam bekerja yang telah ditentukan oleh perusahaan" $\mathrm{Hal}$ serupa dikatakan Gauzali Saydam mendefinisikan "disiplin kerja merupakan sikap kesediaan karyawan dalam bekerja untuk mematuhi atau mentaati segala norma dan peraturan yang berlaku di perusahaan".

Peraturan sangat di perlukan untuk memberikan bimbingan bagi karyawan dalam menciptakan tata tertib yang baik di perusahaan. Dengan tata tertib yang baik, maka produktivitas kerja pada karyawan akan meningkat, halini akan mendukung tercapainya tujuan perusahaan. Kedisiplinan suatu perusahaan dikatakan baik, jika sebagian besar karyawan mentaati peraturanperaturan yang ada.

Dalam disiplin kerja dituntut adanya kesanggupan menghayati peraturan-peraturan, norma-norma, dan tata tertib yang berlaku, sehingga secara sadar mentaatinya. Kesadaran tersebut menandakan telah tertanamnya unsur pengendalian diri dalam mengimplementasikan apa yang telah disadarinya. Sehingga, menunjukan adanya sikap mental dan norma yang tinggi.

Menurut Sjafri dan Aida (2007:122) "disiplin kerja adalah sifat karyawan yang secara sadar mematuhi norma dan peraturan organisasi tertentu dalam bekerja". Kedisiplinan sangat mempengaruhi kinerja karyawan dan perusahaan. Kedisiplinan seharusnya dipandang sebagai bentuk latihan bagi karyawan dalam melaksanakan aturan-aturan perusahaan. Semakin disiplin maka semakin tinggi pula kinerja karyawan dan perusahaan. Disiplin kerja menurut B. Siswanto Sastro Hadiwiryo (2002:291) mendefinisikan sebagai "Suatu sikap menghormati, menghargai, dan patuh atau taat terhadap peraturan yang berlaku, baik yang tertulis maupun yang tidak tertulis, serta sanggup menjalankannya dan tidak mengelak untuk menerima sangsi-sangsinya apabila ia melanggar tugas dan wewenang yang diberikan kepadanya".

Alex S. Nitisemito (2000:199) mengatakan Disiplin kerja yang baik mencerminkan besarnya rasa tanggung jawab seorang karyawan terhadap pekerjaan yang diberikan kepadanya. Hal ini mendorong semangat kerja dan mendukung terwujudnya tujuan karyawan dan masyarakat dengan disiplinnya, pekerjaan akan dilakukan dengan seefektif dan seefisien mungkin.

Wujud kepatuhan dalam disiplin kerja bisa dilihat dari sikap, tingkah laku, dan perbuatan karyawan yang sesuai dengan 
peraturan-peraturan yang ada di dalam perusahaan. Peraturanperaturan tersebut dijadikan pedoman bagi seluruh karyawan sehingga segala sesuatu yang dilakukan terarah pada ketentuan yang di anggap benar, tidak merugikan siapapun.

Disiplin kerja yang efektif dalam perusahaan adalah apabila pemimpin tidak mentolelir perilaku karyawan yang menyimpang, karena hal tersebut dianggap tidak relevan dalam tindakan pendisiplinan. Dalam penegakan disiplin kerja sebaiknya diarahkan kepada perilakunya dan bukan kepada karyawan secara pribadi, karena alasan pendisiplinan adalah untuk meningkatkan produktivitas karyawan.

Beberapa faktor yang mengarah pada praktik disiplin kerja yang efektif di perusahaan menurut Robert L. Mathis dan John $\mathrm{H}$. Jackson (2001:317), diantaranya:

1. Pelatihan untuk manajer

2. Konsistensi dari tindakan pendisiplinan

3. Dokumentasi

4. Tindakan disiplin yang segera

5. Disiplin yang impersonal

Bebererapa penelitian yang relevan antara disiplin kerja denga produktivitas kerja karyawan diantaranya adalah hasil penelitian dari Afni Faunida (2012: 12) menyatakan "hubungan antara disiplin kerja terhadap produktivitas kerja karyawan adalah sangat kuat, yang artinya jika disiplin kerja yang diterapkan dalam perusahaan baik maka produktivitas kerja karyawan juga akan semakin meningkat". Hal serupa di ungkapkan oleh Widodo dan Sunarso (2009:55), "disiplin kerja sangat mempengaruhi terhadap produktivitas karena dengan disiplin kerja maka pekerja mampu melaksanakan pekerjaannya sesuai dengan ilmu yang di dapat dari penyuluhan".

\section{Motivasi Kerja}

Agar dapat mencapai tujuan perusahaan yang maksimal seseorang pemimpin harus dapat memberikan motivasi kerja yang tepat bagi karyawannya. Hal ini tentu saja tidaklah mudah untuk dilakukan karena setiap karyawan mempunyai tingkat kebutuhan yang berbeda-beda. Seorang pemimpin harus mampu memahami dan mengetauhi bagaimana memenuhi kebutuhan karyawannya agar semangat dan produktivitas kerjanya dapat meningkat.

Menurut Adella Hotyda Siregar (2007:23) "motivasi kerja adalah sesuatu yang menimbulkan keinginan bagi seseorang atau pekerja, baik yang berasal dari dalam dirinya maupun yang berasal 
dari luar untuk melaksanakan pekerjaan atau kegiatan dengan rasa tanggung jawab guna mencapai tujuan yang diinginkan". motivasi kerja adalah suatu keadaan yang mendorong atau yang mengerakkan seseorang atau karyawan untuk melakukan suatu tindakan atau pekerjaan tertentu kearah yang lebih baik. Motivasi kerja menurut Osborne yang dikutip oleh Suwatno (2011:171), Motivasion to work describes the forces within an individual that account for the level, direction and persintence of effort expended adequately".

Berdasarkan definisi di atas maka dapat disimpulkan motivasi kerja berkaitan dengan usaha yang dilakukan seseorang atau karyawan dalam rangka mencapai tujuan dalam bekerja yang bersifat individual.

Secara umum dorongan ada 2 macam yang dikenal, yaitu:

a. Dorongan intrinsik adalah motivasi yang timbul dari dalam diri individu.

b. Dorongan ekstrinsik adalah motivasi yang disebabkan oleh adanya rangsangan atau dorongan dari luar.

Dipertegas oleh Faustino Cardoso (2002:181) dorongan digolongkan menjadi dua, yaitu sumber dorongan dari dalam diri (intrinsik) dan sumber dorongan dari luar (ekstrinsik):

a. Intrinsik

1. Kebutuhan-kebutuhan ( needs)

2. Tujuan-tujuan (goals)

b. Ekstrinsik

1. Pegawasan (supervision)

2. Pengahargaan ( rewards)

3. Keamanan kerja ( job-security) Faktor pendorong motivasi yang menyebabkan seseorang bekerja adalah adanya kebutuhan yang harus dipenuhi. Aktivitas dalam bekerja dapat berupa menghasilkan sesuatu dan pada akhirnya bertujuan untuk memenuhi kebutuhan-kebutuhannya.

Menurut A.H Maslow (Ivancevic, 2005:148), kebutuhankebutuhan manusia dapat dikelompokkan ke dalam lima tingkat, yaitu:

1. Physiological needs

2. Safety needs

3. Affiliation or acceptance needs

4. Esteem needs

5. Self actualization Needs

Dalam hal pemberian motivasi kerja ini pimpinan harus mampu melihat situasi serta suasana kerja para karyawan pada saat bekerja, hal ini berguna untuk memberikan motivasi pada saat kapan para karyawan di beri motivasi, baik itu motivasi positif maupun negatif. 
Malayu Hasibuan (2007:35) (membedakan motivasi menjadi:

1. Motivasi positif (incentive positive)

2. Motivasi negative (incentive negative).

Motivasi positif (incentive positive), maksudnya mananjer memotivasi (merangsang) bawahan dengan memberikan hadiah kepada mereka yang berprestasi diatas prestasi standar. Dengan motivasi positif, semangat kerja bawahan akan meningkat karena umumnya manusia senang yang baik-baik saja.

Motivasi negative (incentive negative), maksudnya manajer memotivasi bawahan dengan standar mereka akan mendapat hukuman. Dengan motivasi negatif ini semangat bekerja bawahan dalam jangkah waktu pendek akan meningkat karena mereka takut dihukum, tetapi untuk jangka waktu panjang dapat berakibat kurang baik.

Dalam prakteknya kedua jenis motivasi di atas sering digunakan oleh suatu perusahaan. Penggunaanya harus tepat dan seimbang supaya dapat meningkatkan semangat kerja serta dapat meraih produktivitas kerja yang diinginkan. Yang menjadi masalah adalah kapan motivasi positif atau motivasi negative dapat efektif merangsang gairah kerja karyawan. Motivasi positif efektif untuk jangka waktu panjang sedangkan motivasi negatif efektif untuk jangka waktu pendek. Akan tetapi, manajer harus konsisten dan adil dalam menerapkannya.

Dalam pemberian motivasi seluruh perusahaan mempunyai kesamaan tujuan untuk merangsang dan mendorong individu agar bekerja lebih giat, efisien dan efektif dalam rangka mencapai tujuan perusahaan. Ada beberapa tujuan yang diperoleh dari pemberian motivasi menurut Malayu S.P Hasibuan (2007:36) yaitu:

1. Meningkatkan moral dan kepuasan kerja karyawan.

2. Meningkatkan produktivitas kerja karyawan

3. Mempertahankan kestabilan karyawan perusahaan

4. Meningkatkan disiplin karyawan

5. Mengefektifkan pengadaan karyawan

6. Menciptakan suasana dan hubungan kerja yang baik

7. Meningkatkan loyaritas, kreatifitas dan partisipasi karyawan

8. Meningkatkan tingkat kkesejahteraan karyawan

9. Mempertinggi rasa tanggung jawab karyawan terhadap tugastugasnya. 
10. Meningkatkan efisiensi pengunaan alat-alat dan bahan baku.49

$\begin{array}{lr}\text { Menurut } & \text { Payama } \\ \text { Simanjuntak (Priyono, 2008) }\end{array}$ menyatakan bahwa perbaikan di bidang pengupahan dan jaminan sosial dapat menumbuhkan motivasi kerja dan meningkatkan kemampuan fisik tenaga kerja. Adanya kepastian atas kelangsungan pekerjaan dan penghasilan yang akan di peroleh merupakan daya dorong yang besar untuk meningkatkan produktivitas tenaga kerja. Sedangkan menurut Malayu S.P. Hasibuan (2007), "motivasi penting karena dengan motivasi karyawan mau bekerja keras dan antusias untuk mencapai produktivitas yang tinggi". Dipertegas oleh Winardi dalam Acu Supratman (2006) seseorang yang termotivasi akan melaksanakan upaya yang substansial, guna menunjang kesatuan kerjanya. Motivasi penting karena dengan motivasi di harapkan setiap individu karyawan mau bekerja keras dan antusias untuk mencapai produktivitas kerja yang tinggi.

Hal serupa diungkapkan juga oleh Afni Faunida (2012) menyatakan, "semakin baik pelatihan, disiplin kerja dan motivasi kerja maka semakin tinggi produktivitas kerja karyawan, sedangkan apabila semakin buruk pelatihan, disiplin kerja dan motivasi kerja maka produktivitas kerja juga akan semakin turun".

Berdasarkan uraian tersebut maka dapat disimpulkan bahwa motivasi kerja adalah suatu keadaan yang sengaja di kondisikan agar seseorang terdorong untuk melakukan kegiatan yang sesuai dengan tujuan organisasi dan terpenuhinya kebutuhan hidupnya.

\section{Perumusan Hipotesis}

1. Terdapat pengaruh positif antara motivasi kerja terhadap produktivitas kerja.

2. Terdapat pengaruh positif antara disiplin kerja terhadap produktivitas kerja.

3. Terdapat pengaruh positif antara motivasi kerja dan disiplin kerja produktivitas kerja.

\section{METODOLOGI PENELITIAN}

Metode penelitian yang digunakan adalah metode survei dengan pendekatan korelasional. Dalam penelitian ini yang menjadi populasi adalah seluruh karyawan PT. Kabelindo Murni, Tbk yang berjumlah 287 karyawan. Sedangkan populasi terjangkaunya adalah karyawan pada bagian Production PT. Kabelindo Murni, Tbk yang berjumlah 139 karyawan, 
maka sample yang diambil sebanyak 100 responden.

\section{HASIL PENELITIAN}

Hasil uji perysaratan analisis menunjukkan bahwa data berdistribusi normal, model regresi tidak terjadi multikolinearitas dan tidak adanya masalah heterokedastisitas.

Persamaan regresinya adalah $\hat{Y}=-145.950+0.633 X 1+$ $1.987 \times 2$. Hasil pengujian hipotesis dengan menggunakan uji $F$ diperoleh $F_{\text {hitung }}(29.801)>F_{\text {tabel }}$ $(3,11)$, artinya $\mathrm{HO}$, hingga dapat disimpulkan Motivasi Kerja dan Disiplin

Kerja secara serentak berpengaruh terhadap Produktivitas Kerja.

Uji $t$ untuk mengetahui pengaruh variabel independent secara parsial terhadap variabel dependen, apakah pengaruhnya signifikan atau tidak. Dapat diketahui bahwa $t_{\text {hitung }}$ dari motivasi kerja $(4,903)>t_{\text {tabel }}(1,66)$ hal ini menunjukan bahwa motivasi kerja mempunyai pengaruh positif yang signifikan terhadap produktivitas kerja. Selain itu diketahui juga bahwa thitung dari disiplin kerja $(4.166)>t_{\text {tabel }}(1,66)$ hal ini meunjukkan bahwa disiplin kerja mempunyai pengaruh positif yang signifikan terhadap produktivitas kerja.

Analisis koefisien determinasi (R2) digunakan untuk mengukur seberapa besar kemampuan suatu model menerangkan variasi variabel dependen. Diketahui nilai R2 adalah 0,381. Jadi kemampuan dari variabel Motivasi Kerja dan Disiplin Kerja untuk menjelaskan Produktivitas Kerja secara simultan yaitu $38,1 \%$ sedangkan sisanya sebesar $61,9 \%$ dipengaruhi oleh faktor lain yang tidak diteliti.

\section{KESIMPULAN}

Hasil pengujian hipotesis menghasilkan kesimpulan :

a. Terdapat pengaruh positif yang signifikan antara motivasi kerja dan produktivitas kerja. Artinya jika motivasi kerja tinggi, maka produktivitas kerja juga akan tinggi, dan sebaliknya jika motivasi kerja rendah, maka produktivitas kerja juga akan rendah.

b. Terdapat pengaruh positif yang signifikan antara disiplin kerja dan produktivitas kerja. Artinya jika disiplin kerja tinggi, maka produktivitas kerja juga akan tinggi, dan sebaliknya jika disiplin kerja rendah, maka produktivitas kerja juga akan rendah. 
c. Ada pengaruh positif yang signifikan antara motivasi kerja dan disiplin kerja terhadap produktivitas kerja.

\section{DAFTAR PUSTAKA}

Acu Supratman, Jurnal Percikan Vol. 69 Edisi September 2006

Adella Hotyda Siregar dan Meiwana Sinisula, "Hubungan Antara Motivasi Kerja, Kesejahteraan dan Pelatihan Kinerja", Jurnal Manajemen Mutu. Juli 2007 No. 2

Afni Fuanida, Jurnal ilmu Administrasi Bisnis Vol. 1 No. 1, 2012

Aimee L. Franklin, Javier F. Pagan, Review Of Public Personel Administration, (Columbia: Maret 2006, Vol. 26)

Alex S. Nitisemito, Manajemen Personalia, (Jakarta: Gharia Indonesia, 2000)

B. Siswanto Sastrohadiwiryo, Manajemen Tenaga Kerja Indonesia, (Jakarta: Bumi Aksara, 2002)

Burhanudin A, Administrasi Kepegawaian Suatu Tinjauan Analitik, (Jakarta: Pradnya Paramita, 2001)
Damodar N. Gujarati, Basic Econometrics, (Mc Graw Hill, USA, 2003)

Edy Sutrisno, Budaya Organisasi, (Jakarta: Kencana, 2010)

Eliza Herijulianti, Pendidikan Kesehatan Gigi, (Jakarta: EGC, 2001)

Endang Sri Astuti dan Resminingsih, Bahan Dasar Untuk Pelayanan Konseling Pada Satuan Pendidikan Menengah Jilid 1, (Jakarta: Grasindo, 2010)

Faustino Cardoso Gomes, Manajemen Sumber Daya Manusia, Ed. 1, (Yogyakarta: ANDI, 2002)

Faustino Cardoso Gomes, Manajemen Sumber Daya Manusia, Edisi ke-2 (Yogyakarta: ANDI, 2009)

Gauzali Saydam, Manajemen Sumber Daya Manusia, (Jakarta: Gunung Agung, 2000)

Husein Umar, Metode Riset dan

Bisnis, (Jakarta: PT. Gramedia Pustaka Utama, 2002)

Husein Umar, Riset Sumber Daya

Manusia, (Jakarta: PT.

Gramedia Pustaka Utama, 2005)

Husein Usman, Manajemen Teori: Praktik dan Riset Pendidikan, (Jakarta: Bumi Aksara, 2006) 
I.G Wursanto, Manajemen Kepegawaian 2, (Yogyakarta: Kanisius, 2001)

Ivancevic, John M., Robert Konopaske, Michael T. Matteson, Perilaku dan Manajemen Organisasi, (Jakarta: Erlangga, 2005)

Jannati Tangngisalu, Jurnal IImiah Bongaya (Manajemen \& Akuntansi), No. IV: Oktober 2008

Malayu S.P. Hasibuan, Organisasi Dan Motivasi, Dasar Peningkatan Produktivitas (Jakarta: PT Bumi Aksara, 2007)

Mapparenta, Jurnal Economic Resourrces Vol. 11 No. 30, Februari, 2010

Pandji Anoraga, Manajemen Bisnis, (Jakarta: Rineka Cipta, 2004) Priyono Tjiptoheriyanto dan Lailan Nagib, Pengembangan Sumber Daya Manusia, (Jakarta: Lipi Press, 2008)

Rabianur Lubis, "Hubungan Antara Disiplin Kerja dan Motivasi Kerja Terhadap Produktivitas Kerja Dosen di Lingkungan Universitas Islam 45 Bekasi", Vol. 8 No. 1, 2012

Raja Bambang Sutikno, The Power of Empathy in Leadership, (Jakarta: PT. Gramedia Pustaka Utama, 2007)
Robert L. Mathis dan John $\mathrm{H}$. Jackson, Manajemen Sumber Daya Manusia (Jakarta: Salemba Empat, 2001)

Sedarmayanti, Tata Kerja dan Produktivitas Kerja (Bandung: CV. Mandar Maju, 2011)

Sjafri Mangkuprawira dan Aida Vitalaya Hubeis, Manajemen Mutu Sumber Daya Manusia, (Jakarta: Ghalia Indonesia, 2007)

Sondang P. Siagian, Manajemen Sumber Daya Manusia, (Bandung: Bumi Aksara, 2004)

Sugiyono, Metode Penelitian Pendidikan, (Bandung: Alfabeta, 2006),

Sugiyono, Statistik untuk Penelitian. (Bandung: Alfabeta, 2000)

Suharsimi Arikunto, Manajemen Penelitian, (Jakarta: Rineka Cipta, 2009)

Suwatno dan Donni Juni Priansa, Manajemen SDM dalam Organisasi Publik dan Bisnis, (Bandung: Alfabeta, 2011)

Tjutju Y. Dan Suwatno, Manajemen Sumber Daya Manusia, (Bandung: CV. Alfabeta, 2009)

Tjutju Yuniarsih dan Suwatno, Manajemen Sumber Daya Manusia, Teori, Aplikasi dan 
Isu Penelitian (Bandung: Widodo dan Sunarso, Jurnal Alfabeta, 2009)

Triton P.B., Manajemen Sumber Daya Manusia : Perspektif Partnership dan Kolektivitas, (Yogyakarta: Tugu Publisher, 2007)

Veithzal Rivai, Manajemen Sumber Daya Manusia Untuk Perusahaan, (Jakarta: Raja Grafindo, 2005) Manajemen Sumber Daya Manusia Vol. 3 No. 1, Juni 2009

Zainal Mustafa Eq, Pengaruh Kecerdasan Emosi Terhadap Produktivitas Kerja Karyawan, (Jurnal Kajian Bisnis dan Manajemen), Vol. 9 No. 2, Juni 2007.

Wibowo, Manajemen Kinerja, (Jakarta: PT. Raja Grafindo Persada, 2008) 